\title{
Venous insufficiency: Differences in the content of trace elements. A preliminary report
}

\author{
Agnieszka Rusak ${ }^{1, B-D}$, Ewa Karuga-Kuźniewska 2,A,E, Benita Wiatrak ${ }^{3, D, E}$, Maria Szymonowicz, ${ }^{4, C, D}$, \\ Mateusz Stolarski, ${ }^{5, B}$, Małgorzata Radwan-0 Oczko ${ }^{6, B}$, Rafał J. Wiglusz ${ }^{7,-F}$, Paweł Pohl ${ }^{8, A, C}$, Zbigniew Rybak ${ }^{4, D-F}$ \\ 1 Division of Histology and Embryology, Department of Human Morphology and Embryology, Wroclaw Medical University, Poland \\ 2 Division of Infectious Diseases of Animals and Veterinary Administration, Department of Epizootiology and Clinic of Bird and Exotic Animals, Faculty of Veterinary Medicine, \\ Wroclaw University of Environmental and Life Sciences, Poland \\ ${ }^{3}$ Department of Basic Medical Sciences, Wroclaw Medical University, Poland \\ ${ }^{4}$ Department of Experimental Surgery and Biomaterials Research, Wroclaw Medical University, Poland \\ ${ }^{5}$ Department of Trauma Surgery, Knappschaftskrankenhaus Bochum-Langendreer, University Hospital Bochum, Germany \\ ${ }^{6}$ Department of Periodontology, Wroclaw Medical University, Poland \\ ${ }^{7}$ Institute of Low Temperature and Structure Research, Polish Academy of Sciences, Wrocław, Poland \\ ${ }^{8}$ Division of Analytical Chemistry and Chemical Metallurgy, Faculty of Chemistry, Wroclaw University of Science and Technology, Poland \\ A - research concept and design; $\mathrm{B}$ - collection and/or assembly of data; $\mathrm{C}$ - data analysis and interpretation; \\ $D$ - writing the article; $E$ - critical revision of the article; $F$ - final approval of the article
}

\section{Address for correspondence}

Agnieszka Rusak

E-mail: rusakagn@gmail.com

\section{Funding sources}

Financial support of the National Science Centre (Poland) in the course of realization of the project "Preparation and characterization of nanoapatites doped with rare earth ions and their biocomposites" (No. UM0-2012/05/E/ST5/03904).

Conflict of interest

None declared

Received on September 15, 2016

Reviewed on December 14, 2016

Accepted on February 9, 2017

DOI

10.17219/acem/68902

\section{Copyright}

Copyright by Author(s)

This is an article distributed under the terms of the

Creative Commons Attribution Non-Commercial License

(http://creativecommons.org/licenses/by-nc-nd/4.0/)

\section{Abstract}

Background. Venous insufficiency is still a serious clinical problem. The exact cause and molecular mechanisms of this disease are still unknown. In this study, we try to identify whether there is a difference in the level of trace elements between healthy and pathological veins. Our results show that insufficient veins have different levels of some trace elements: magnesium, calcium, manganese, and silicon compared to control samples. This study could lead to a better understanding of the molecular causes of venous insufficiency and may help to develop better methods of treatment.

Objectives. Nowadays, venous diseases are a very common clinical phenomenon. Venous insufficiency is thought to be one of the most common vein diseases. The exact mechanisms of its etiology are still unknown, although from a clinical point of view some risk factors include gender, age, changing hormone levels, heredity, and standing or sitting for long periods. An imbalance in trace elements could also play a crucial role in the development and/or progression of venous insufficiency.

Material and methods. The trace element content in varicose vein walls and in normal vein walls was measured using an inductively coupled plasma-optical emission spectrometer (ICP-OES) after sample mineralization. Statistical analysis (the Mann-Whitney U test and the Friedman ANOVA) was performed to compare insufficient veins to controls (healthy veins).

Results. This study found statistically significant higher magnesium $(\mathrm{Mg})$ ion levels in varicose veins compared to controls ( $p=0.0067)$ and differences close to statistical significance in calcium (Ca), manganese (Mn), and silicon (Si) ion levels.

Conclusions. The results obtained could indicate oxidative stress occurring in chronic venous insufficiency as well as free radical neutralization pathways due to superoxide dismutase (SOD) activity with $\mathrm{Mg}, \mathrm{Mn}$ and copper (Cu) ion involvement. Our results are consistent with literature data and are preliminary in nature.

Key words: trace elements, venous insufficiency, venous pathology 


\section{Introduction}

Venous disease with concomitant varicose veins is presently a very common clinical phenomenon consisting of the destruction of vein valves, backward blood flow (venous reflux) and dilated veins. ${ }^{1}$ This in turn, may lead to serious complications, such as thrombosis, skin changes and leg ulcers. There are many genetic, hormonal and environmental factors affecting the development of varicose veins. The exact mechanism of their formation has not been identified. The main destructive factor is venous hypertension, which may lead to the remodeling of vein walls and vein valves. ${ }^{2,3}$ It is thought that long-term high pressure in veins may activate matrix metalloproteinases (MMPs), initiate coagulation and complement cascades, and activate platelets, leukocytes and macrophages as well. ${ }^{1,2,4}$ Matrix metalloproteinases destroy the extracellular matrix, affect smooth muscle cells, and change the properties of the endothelium layer. These processes tend to reduce the flexibility of vein walls. Activated leukocytes escape via damaged endothelium outside the capillaries, starting inflammatory processes. Then, proteins like fibrinogen build a cuff around the capillaries, interfering with the gas exchange between the blood and the extracellular environment, which then leads to further damage of vein walls. ${ }^{1,2}$

The role of trace elements in vein pathology is not yet fully understood, but it is known that they play a significant role in tissue metabolism. Many studies suggest that iron (Fe) could be important in the development of venous diseases, but the cause of these iron deposits in the legs of patients with venous diseases is not yet known. ${ }^{5}$ It has been suggested that this process is connected with activated MMPs or free radicals. ${ }^{5-7}$ There is also a hypothesis that iron is not a direct cause of venous abnormalities, but only a factor which intensifies the autoimmune response. ${ }^{8}$ Zinc (Zn), manganese $(\mathrm{Mn})$ and copper $(\mathrm{Cu})$ ions are associated with an active center of superoxide dismutase (SOD) and participation in free radical neutralization. ${ }^{9-11}$ It is thought that reactive oxygen species (ROS) play a significant role in the development of the endothelial dysfunctions which are connected with venous diseases, such as varicose veins and venous ulcers. ${ }^{12-14} \mathrm{Zinc}, \mathrm{Cu}$ and Fe ions also participate in free oxygen radical formation and may be involved in damage leading to chronic venous insufficiency. ${ }^{7,15}$ Zinc is an important trace element for the immune system. ${ }^{16,17}$ In in vitro tests, high levels of $\mathrm{Zn}$ led to cell apoptosis. Most of the zinc (90\%) in the human body is contained in the muscles and bones. ${ }^{16}$ Copper is also an important trace element for human health - the body needs $\mathrm{Cu}$ in the appropriate amount, but excessive amounts are confirmed to have toxic properties. ${ }^{18,19}$ Copper deficiency causes many abnormalities, e.g., problems with the absorption of iron leading to cellular iron deficiency, disorders of the immune system and weakness of the walls of the blood vessels. ${ }^{7,20,21}$
Copper is needed as a structural component or catalyst by many proteins. ${ }^{7}$ One of the important copper-containing proteins relevant to the construction of the blood vessels is lysyl oxidase. It is responsible for stiffness and elasticity as a result of the fact that it allows bonding between collagen and elastin., ${ }^{72}$ Manganese is needed for the proper functioning and metabolism of cells. ${ }^{23}$ However, in vivo and in vitro studies showed the toxic properties of $\mathrm{Mn}$ in high doses, especially for the central nervous system and PC12 cells (used as an in vitro model of neuronal cells). ${ }^{23-25}$

Age-related changes were previously reported in the arteries and veins. ${ }^{26}$ The magnesium $(\mathrm{Mg})$ content in the veins increases with aging, which may play a role in the development of vein wall diseases. ${ }^{27}$ Magnesium $\mathrm{Mg}^{2+}$ ions are known as an enzyme cofactor. ${ }^{28}$ Signaling pathways, ATPase activity, and the channel and metabolic regulation of the cell cycle are all dependent on $\mathrm{Mg}^{2+}$ content. Magnesium deficiency is connected with the occurrence of many disorders, such as osteoporosis, hypertension, heart arrhythmia, impaired glucose tolerance, and serum cholesterol. ${ }^{29-31}$ A reduced level of magnesium also increases oxidative stress and can reduce erythrocyte SOD concentrations. ${ }^{30}$

Calcium $(\mathrm{Ca})$ is involved in many metabolic processes. It occurs in the human body mainly in the bones and teeth in the form of calcium hydroxyapatite. Accumulated calcium in the bones constitutes a reserve for the functioning of the body. ${ }^{32}$ Calcium ions are used to carry cellular signals and as transporters across cell membranes. ${ }^{33,34}$ They also regulate intracellular mechanisms by binding to proteins. The cellular level of $\mathrm{Ca}^{2+}$ is precisely regulated - a significant increase in the calcium level can lead to apoptotic changes. ${ }^{34}$ Metabolic processes involving $\mathrm{Ca}$ ions are critical for the functioning of the vessels, muscles, nerves, and the endocrine system. ${ }^{32}$

Silicon ( $\mathrm{Si})$ is an important element in the biology of all living organisms - small amounts of this element are essential for their proper functioning. ${ }^{35,36}$ It plays an important role in the connective tissue (bone, cartilage, skin, and blood vessels). ${ }^{37,38}$ It is believed that $\mathrm{Si}$ is associated with the content of collagen and glycosaminoglycans in the connective tissue matrix. ${ }^{38,39}$ Changes in the Si level of pathological tissues have been observed (e.g., in atherosclerotic tissue). ${ }^{40}$ In vitro studies suggest that $\mathrm{Si}$ could have neuroprotective or neurotoxic properties (depending on the concentration). ${ }^{41}$

In our study, we determined the content of trace elements - $\mathrm{Cu}, \mathrm{Fe}, \mathrm{Mn}, \mathrm{Mg}, \mathrm{Zn}, \mathrm{Ca}$, and $\mathrm{Si}$ - found in human veins affected by chronic venous insufficiency and compared this data with the levels of the same trace elements found in healthy, sufficient human veins. It was confirmed that the concentrations of elements in tissue are often correlated with each other. ${ }^{42}$ For this reason, the opportunity to check the correlation of various trace elements in healthy and pathological veins was taken. 


\section{Material and methods}

This study was conducted over a span of 2 years, between 2013 and 2014, at the Wroclaw Medical University and the Institute of Low Temperature and Structure Research, Polish Academy of Sciences. It was performed in compliance with the ethical principles of the Declaration of Helsinki and Good Clinical Practice. Legal representatives read, signed and dated the form before taking part in any study activity. Consent from the Bioethical Commission of Wroclaw Medical University was granted for the study (No. KB-87/2013).

\section{Reagents and solutions}

EMSURE ${ }^{\circledR}$ ACS grade reagents, i.e., concentrated $\mathrm{HNO}_{3}$ (65\%), $\mathrm{HCl}(36 \%)$ and $\mathrm{H}_{2} \mathrm{O}_{2}(30 \%)$ solutions were purchased from Merck Millipore (Merck KGaA, Darmstadt, Germany). Aqua regia was freshly prepared by mixing concentrated $\mathrm{HCl}$ and $\mathrm{HNO}_{3}$ solutions at a 3:1 volume ratio. Deionized water from an EASYpure ${ }^{\mathrm{TM}}$ water purification system (Barnstead Thermolyne Corp., Dubuque, USA) was used throughout. A Certipur ${ }^{\circledR}$ multi-element stock $(1000 \mu \mathrm{g} / \mathrm{mL})$ ICP standard solution IV (Merck KGaA) was used for preparing simple and matrix-matching standard solutions for the calibration of the inductively coupled plasma-optical emission spectrometry (ICP-OES) instrument.

\section{Samples and their preparation}

An inorganic solution, made directly from human veins, was fabricated using microwave-assisted wet digestion, whereby the disinfected human veins were combined with $\mathrm{HNO}_{3}$ and $\mathrm{H}_{2} \mathrm{O}$ as well as $\mathrm{NH}_{4} \mathrm{OH}$, for $\mathrm{pH}$ control. First of all, the received disinfected human veins were subjected to thermal treatment using an electric furnace at a temperature of $550^{\circ} \mathrm{C}$ for $1 \mathrm{~h}$. Following typical preparation procedures for a final product containing all microelements, the inorganic powder was first dissolved in an excess of $\mathrm{HNO}_{3}$ in order to create an inorganic solution. This inorganic solution was then transferred into a teflon vessel and placed in a microwave reactor. After $60 \mathrm{~min}$ of microwave-stimulated hydrothermal processing at $200^{\circ} \mathrm{C}$, and under an autogenous pressure of $45 \mathrm{~atm}$, the $\mathrm{pH}$ of the dispersion was then adjusted to approx. 7 with the addition of $\mathrm{NH}_{4} \mathrm{OH}$. The resulting composition of the prepared solutions was then determined by inductively coupled plasma-optical emission spectrometry (ICP-OES).

\section{Apparatus}

A bench-top optical emission spectrometer, model 720 (Agilent, Santa Clara, USA), with an axially viewed ArICP and a 5-channel peristaltic pump, was used to measure the concentrations of $\mathrm{Cu}, \mathrm{Mn}, \mathrm{Fe}, \mathrm{Mg}, \mathrm{Zn}, \mathrm{Ca}$, and $\mathrm{Si}$ (trace elements). The instrument was equipped with a high-resolution echelle-type polychromator and a VistaChip II CCD detector (Agilent) cooled down to $-35^{\circ} \mathrm{C}$ on a triple-stage Peltier device. The plasma was sustained in a standard 1-piece, low-flow, extended quartz torch with a $2.4 \mathrm{~mm}$ inside diameter injector tube. A single-pass glass cyclonic spray chamber and a OneNeb pneumatic concentric nebulizer made of a high-tech PFA and PEEK polymers were used to introduce the sample solutions by pneumatic nebulization. Operating conditions recommended by the manufacturer for solutions containing high levels of dissolved solids were applied: an RF power of $1200 \mathrm{~W}$, a plasma gas flow rate of $15.0 \mathrm{~L} \mathrm{~min}^{-1}$, an auxiliary gas flow rate of $1.5 \mathrm{~L} \mathrm{~min}^{-1}$, a nebulizer gas flow rate of $0.75 \mathrm{~L} \mathrm{~min}^{-1}$, a sample flow rate of $0.75 \mathrm{~mL} \mathrm{~min}^{-1}$, a stabilization delay of $15 \mathrm{~s}$, a sample uptake delay of $30 \mathrm{~s}$, a rinse time of $10 \mathrm{~s}$, a replicate read time of $1 \mathrm{~s}$, and 3 replicates. A fitted background mode with 7 points per line profile was applied for the background correction. Background-corrected intensities of analytical lines were used for calibration graphs.

\section{Characteristic of groups}

In this study, 2 different groups of patients were enrolled. One group of 11 patients (study group) was referred for surgery due to symptomatic vein insufficiency in 1 or both legs according to Clinical, Etiological, Anatomical, and Pathophysiological (CEAP) classification C2S, Ep, As, or Pr. The other group, consisting of 14 patients (control group), underwent cardiac coronary bypass grafting due to symptomatic arterial coronary insufficiency. The proximal and distal segments of the great saphenous vein were obtained from patients via a striping procedure (study group), while the patients with healthy veins (control group) underwent elective coronary artery bypass grafting, whereby excess vein was obtained from the proximal and distal vein segments. Patients were matched for age, sex and major risk factors (data not shown). Vessel segments were harvested using a non-touch technique before surgical distension or rapid removal. The segments were immediately transferred to physiological saline solution and stored in a refrigerator at a temperature of $-20^{\circ} \mathrm{C}$.

\section{Statistical analysis}

The results were statistically analyzed using the STATISTICA v. 12 software (StatSoft, Tulsa, USA). The ShapiroWilk test showed no normal distribution in the samples. The Mann-Whitney U test, Spearman's rank order correlation (R), Friedman ANOVA, and Kendall's coefficient of concordance were applied.

\section{Results}

Differences in the levels of elemental ions in insufficient veins compared to control samples were observed and analyzed in each group (the Friedman ANOVA) (Fig. 1). 

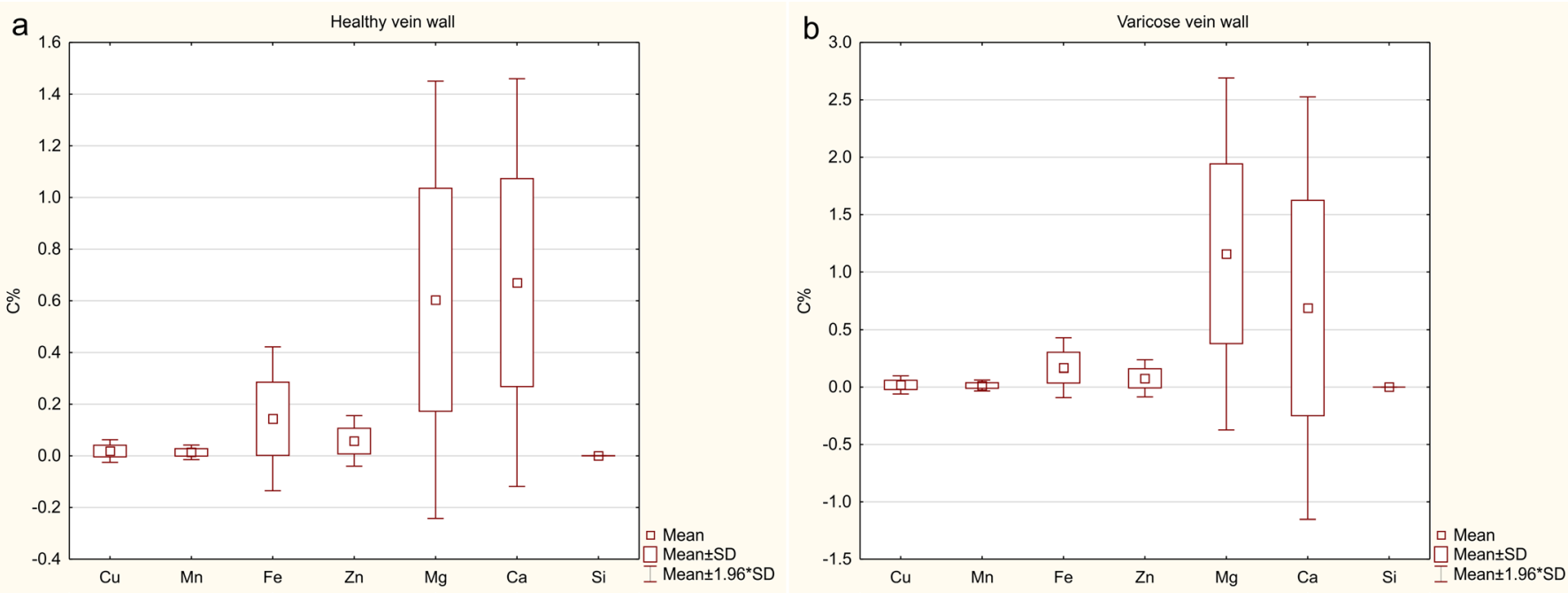

Fig. 1. Distribution of trace elements in: a) the group of insufficient veins, Friedman ANOVA ( $N=11, d f=6) p=0.000$, Kendall's coefficient of concordance: $p=0.970$; and b) the group of normal, healthy veins (control group), Friedman ANOVA $(N=14, d f=6) p=0.00000$, Kendall's coefficient of concordance: $p=0.925$

C\% - mean \% mass concentration; SD - standard deviation.

Table 1. Spearman's rank order correlation (R) in the study group of insufficient veins

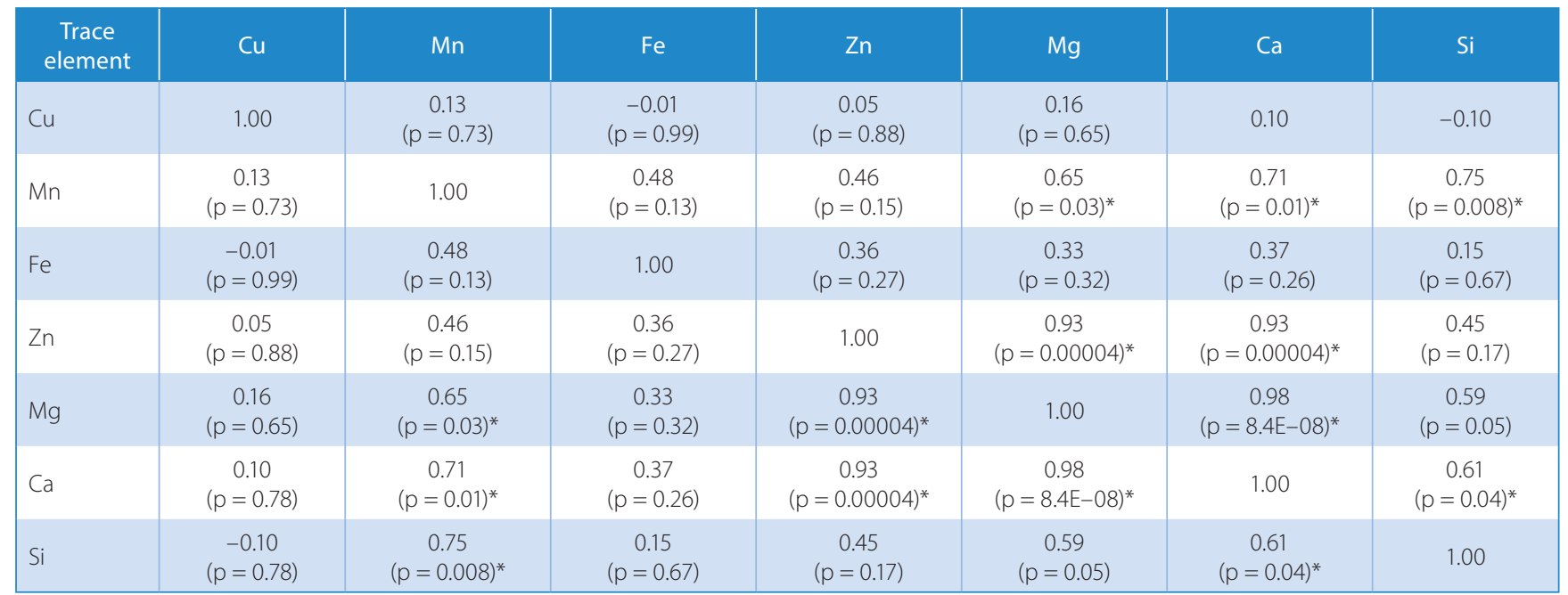

* statistically significant values $(p<0.05)$.

Statistically significant differences (the Mann-Whitney U test) compared to controls were observed (Fig. 2). A statistically significant difference $(\mathrm{p}=0.007)$ in the $\mathrm{Mg}$ ion level in varicose veins compared to controls was noted (Fig. 2e). Differences in Mn ( $\mathrm{p}=0.067), \mathrm{Ca}(\mathrm{p}=0.085)$ and $\mathrm{Si}(\mathrm{p}=0.075)$ levels were close to the margin of statistical significance (Fig. 2b, 2f, 2g). The concentrations of microelements in the studied human veins are presented as mean \% mass concentration $(\mathrm{C} \%)$ of trace elements in the mineral part of tissue samples.

A statistically significant ( $\mathrm{p}>0.05)$, positive and strong correlation (Spearman's rank order correlation) between the levels of some trace elements were observed for the study group (Table 1) and control group (Table 2). In the investigated group, correlations between the $\mathrm{Ca}$ and $\mathrm{Mn}$ ion levels $(\mathrm{R}=0.71 ; \mathrm{p}=0.01)$, and the $\mathrm{Ca}$ and $\mathrm{Zn}$ levels $(\mathrm{R}=0.93 ; \mathrm{p}=0.00004)$ were observed. In the control group, a correlation between these pairs was also observed
$(\mathrm{R}=0.58 ; \mathrm{p}=0.03$ and $\mathrm{R}=0.88 ; \mathrm{p}=0.00003$, respectively), with a common correlation for both groups being noted.

\section{Discussion}

Similar research has already been done, but there is very little literature available for comparison. The pioneer study of ferrous content in veins was performed by Krzyściak etal. ${ }^{6}$ One of the mechanisms involved in chronic venous disease is the destructive effect of free oxygen and free nitrogen radicals. The authors showed that Fe ions were involved in the oxidative damage mechanism which caused tissue altering via the Fenton reaction. Oxidative stress correlated with insufficiency in the venous tissue, and increased SOD activity was observed compared to normal venous tissue. ${ }^{15}$ An increased level of iron in the skin of patients with chronic venous disease was described 
a
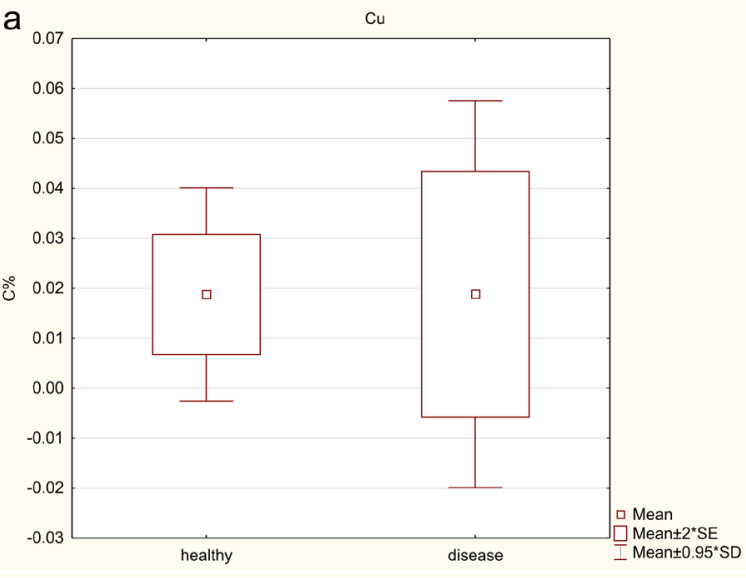

C
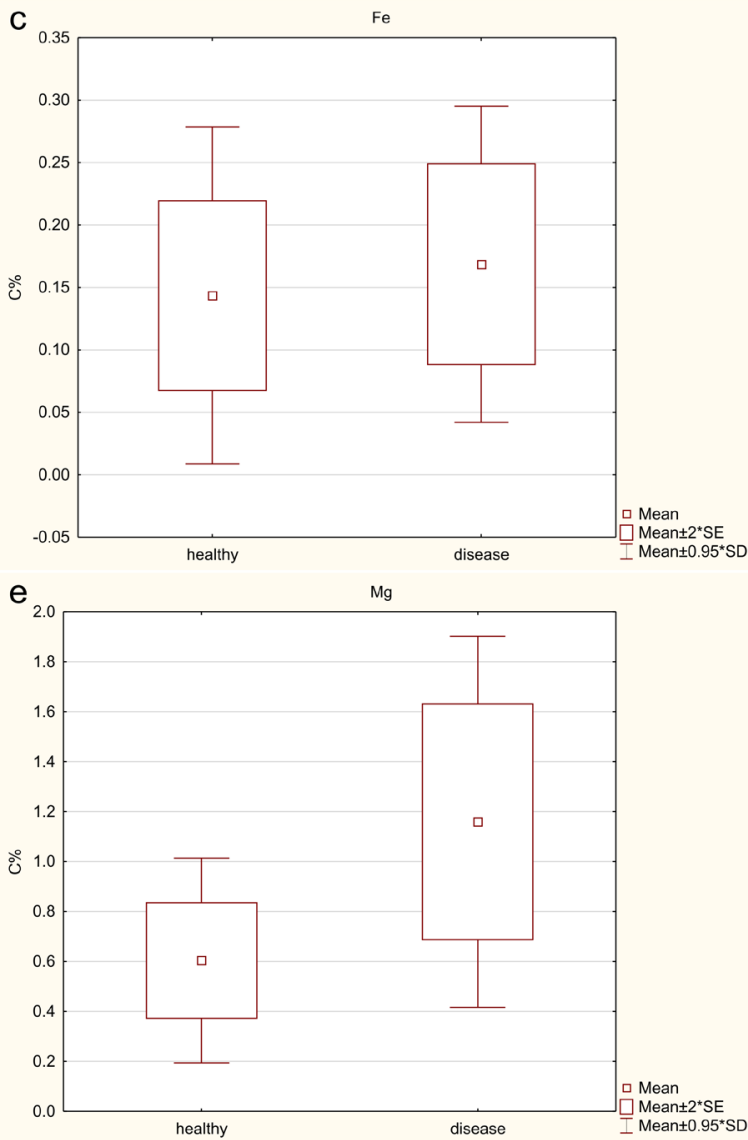

$g_{0.007}$

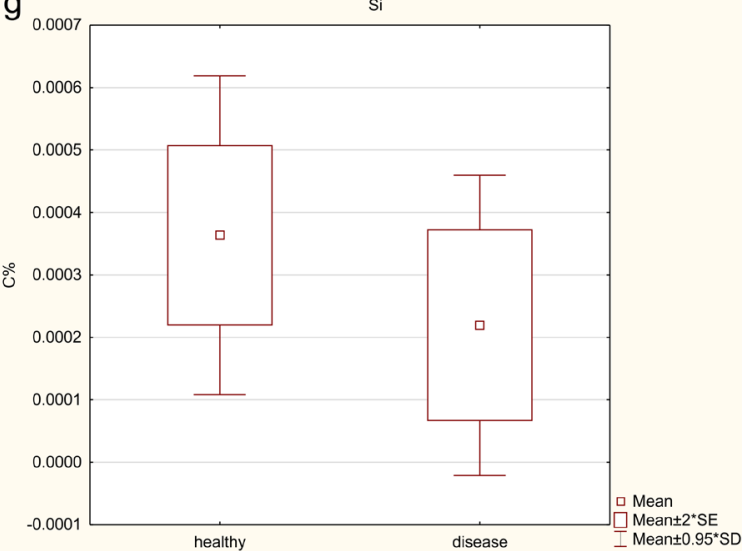

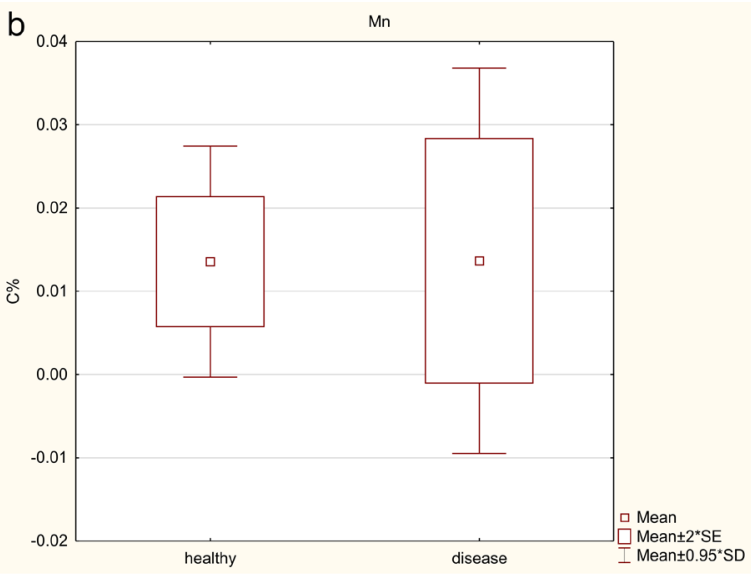

d
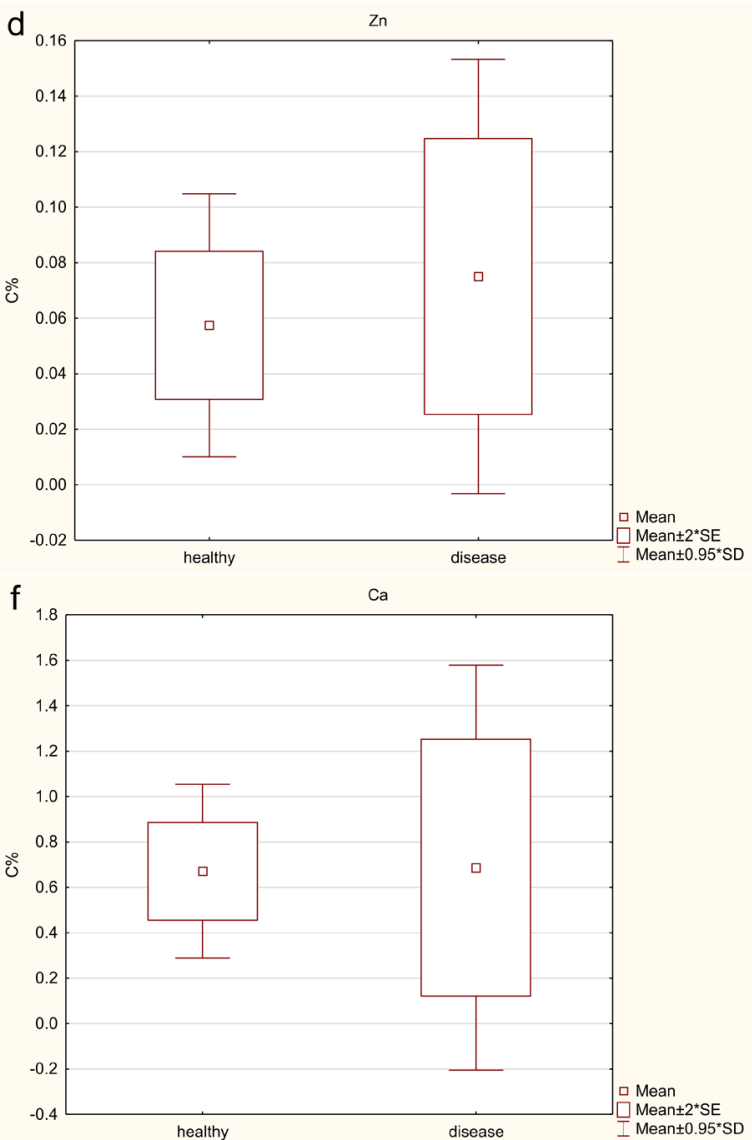

Fig. 2. Levels of ions, presented as mean \% mass concentration (C\%) of trace elements in the mineral part of tissue samples in insufficient veins compared to healthy veins (Mann-Whitney $U$ test): $a)$ Cu ions ( $p=0.723) ; b)$ Mn ions ( $p=0.067)$; $)$ Fe ions ( $p=0.529)$; $d) Z n$ ions ( $p=0.848)$; $)$ Mg ions ( $p=0.007)$; f) Ca ions ( $p=0.085)$; and g) Si ions ( $p=0.075$ )

SE - standard error; SD - standard deviation. 
Table 2. Spearman's rank order correlation (R) in the control group (c) of normal veins

\begin{tabular}{|c|c|c|c|c|c|c|c|}
\hline $\begin{array}{c}\text { Trace } \\
\text { element }\end{array}$ & Cuc & $\mathrm{MnC}$ & $\mathrm{Fec}$ & $\mathrm{Znc}$ & $\mathrm{Mg} \mathrm{C}$ & $\mathrm{Cac}$ & $\mathrm{Sic}$ \\
\hline Cuc & 1.00 & $\begin{array}{c}0.32 \\
(p=0.27)\end{array}$ & $\begin{array}{c}-0.006 \\
(p=0.98)\end{array}$ & $\begin{array}{c}0.74 \\
(p=0.002)^{*}\end{array}$ & $\begin{array}{c}0.13 \\
(p=0.65)\end{array}$ & $\begin{array}{c}0.59 \\
(p=0.02)^{*}\end{array}$ & $\begin{array}{c}0.29 \\
(p=0.31)\end{array}$ \\
\hline$M \cap C$ & $\begin{array}{c}0.32 \\
(p=0.27)\end{array}$ & 1.00 & $\begin{array}{c}0.16 \\
(p=0.56)\end{array}$ & $\begin{array}{c}0.54 \\
(p=0.05)^{*}\end{array}$ & $\begin{array}{c}0.08 \\
(p=0.78)\end{array}$ & $\begin{array}{c}0.58 \\
(p=0.03)^{*}\end{array}$ & $\begin{array}{c}0.23 \\
(p=0.42)\end{array}$ \\
\hline $\mathrm{FeC}$ & $\begin{array}{c}-0.006 \\
(p=0.98)\end{array}$ & $\begin{array}{c}0.16 \\
(p=0.56)\end{array}$ & 1.00 & $\begin{array}{c}0.40 \\
(p=0.16)\end{array}$ & $\begin{array}{c}0.90 \\
(p=0.00001)^{*}\end{array}$ & $\begin{array}{c}0.33 \\
(p=0.25)\end{array}$ & $\begin{array}{c}0.16 \\
(p=0.59)\end{array}$ \\
\hline Znc & $\begin{array}{c}0.74 \\
(p=0.002)^{*}\end{array}$ & $\begin{array}{c}0.54 \\
(p=0.05)^{*}\end{array}$ & $\begin{array}{c}0.40 \\
(p=0.16)\end{array}$ & 1.00 & $\begin{array}{c}0.46 \\
(p=0.09)\end{array}$ & $\begin{array}{c}0.88 \\
(p=0.00003)^{*}\end{array}$ & $\begin{array}{c}0.61 \\
(p=0.02)^{*}\end{array}$ \\
\hline $\mathrm{MgC}$ & $\begin{array}{c}0.13 \\
(p=0.65)\end{array}$ & $\begin{array}{c}0.08 \\
(p=0.78)\end{array}$ & $\begin{array}{c}0.90 \\
(p=0.00001)^{*}\end{array}$ & $\begin{array}{c}0.46 \\
(p=0.09)\end{array}$ & 1.00 & $\begin{array}{c}0.26 \\
(p=0.36)\end{array}$ & $\begin{array}{c}0.18 \\
(p=0.54)\end{array}$ \\
\hline $\mathrm{CaC}$ & $\begin{array}{c}0.59 \\
(p=0.02)^{*}\end{array}$ & $\begin{array}{c}0.58 \\
(p=0.03)^{*}\end{array}$ & $\begin{array}{c}0.33 \\
(p=0.25)\end{array}$ & $\begin{array}{c}0.88 \\
(p=0.00003)^{*}\end{array}$ & $\begin{array}{c}0.26 \\
(p=0.36)\end{array}$ & 1.00 & $\begin{array}{c}0.50 \\
(p=0.07)\end{array}$ \\
\hline
\end{tabular}

* statistically significant values $(p<0.05)$.

by Myers in $1966 .{ }^{43}$ Degradation of hemoglobin, as well as Fe release, was associated with erythrocyte dysfunction. Moosavi et al. showed increased concentrations of iron and copper in the walls of varicose veins compared to controls, using a proton-induced X-ray emission (PIXE) analysis. ${ }^{44}$

Determining the content of trace elements in tissues is still a subject of research, though environmental contamination due to metal ions and the bioaccumulation ratio needs to be assessed as well. ${ }^{45,46}$ The level of trace elements in tissue is a reflection of the general health and metabolic status of the individual. ${ }^{47}$ The level of metal ions significantly depends on the type and location of the tissue being measured. Determining the level of trace elements may have a diagnostic application in such tissues as brain and blood serum. ${ }^{47,48}$

The level of SOD, oxidative DNA damage, and increased levels of iron, copper and zinc ions were also observed. ${ }^{27,30}$ SOD functions as a free radical scavenger. In oxidative stress conditions, increased antioxidant activity must be correlated with increased levels of enzymatic cofactors like $\mathrm{Zn}, \mathrm{Mn}$ and $\mathrm{Cu}$ ions. ${ }^{15}$

The analysis of our results shows the differences between normal and insufficient veins. The $\mathrm{Cu}, \mathrm{Zn}, \mathrm{Mn}$, and $\mathrm{Ca}$ ion levels had higher maximum values and slightly higher mean values compared to normal. Increased levels of these ions were observed in chronic venous insufficiency (CVI). Moreover, the $\mathrm{Mn}$ and $\mathrm{Ca}$ ion levels were close to being statistically significantly different from the control. These results are consistent with the literature and suggest a role of an SOD-, Cu-, Mn-, and Zn-dependent enzyme in CVI. Even though only a few articles dealing with a similar subject were found, the results obtained in this study were consistent with the data in the existing literature. ${ }^{6,15}$

The iron ion levels were the highest detected, but the difference between altered and normal veins was not statistically significant.
The reduction of vein wall elasticity is one of the symptoms of venous insufficiency, which, in our opinion, could be associated with a decreased level of silicon, considering the role of this trace element in fiber synthesis. Our study shows decreased levels of $\mathrm{Si}$ in insufficient veins. These levels were considerably lower, as predicted, and the results were close to statistically significant. To our knowledge, at present, there are no other reports in the literature about the Si levels in similar research.

We found that the magnesium ion levels were higher in varicose veins compared to the control $(p=0.0067)$. This result may suggest that magnesium ions play an important role in the mechanism which occurs during venous insufficiency, and very probably in vein wall structures as well.

Differences in the correlation patterns of trace elements between normal and varicose veins may suggest homeostatic destabilization associated with vein disease. In addition, they could also suggest a significant role of trace elements in chronic venous disease.

The current study is only a preliminary one. There is a need to perform further research, with an increased size of the study and control groups. Future studies are planned to assess the impact of gender on the levels of trace elements in a larger group.

\section{Conclusions}

This paper shows the levels of certain ions in insufficient and normal veins, particularly the differences between the concentrations of $\mathrm{Mg}, \mathrm{Mn}, \mathrm{Ca}$, and $\mathrm{Si}$. This study is preliminary in nature, but the data obtained suggests that the oxidative damage mechanism is involved in the development of varicose veins and chronic venous insufficiency. 


\section{References}

1. Raffetto JD, Khalil RA. Mechanisms of varicose vein formation: Valve dysfunction and wall dilation. Phlebology. 2008;23:85-98.

2. Kucukguven A, Khalil RA. Matrix metalloproteinases as potential targets in the venous dilation associated with varicose veins. Curr Drug Targets. 2013;14:287-324.

3. Simka M. Cellular and molecular mechanisms of venous leg ulcers development: The "puzzle" theory. Int Angiol. 2010;29:1-19.

4. Raffetto JD, Qiao X, Koledova VV, Khalil RA. Prolonged increases in vein wall tension increase matrix metalloproteinases and decrease constriction in rat vena cava: Potential implications in varicose veins. J Vasc Surg. 2008;48:447-456.

5. Zamboni $P$, Izzo M, Tognazzo S, et al. The overlapping of local iron overload and HFE mutation in venous leg ulcer pathogenesis. Free Radic Biol Med. 2006;40:1869-1873.

6. Krzyściak W, Kowalska J, Kózka M, Papież MA, Kwiatek WM. Iron content (PIXE) in competent and incompetent veins is related to the vein wall morphology and tissue antioxidant enzymes. Bioelectrochemistry. 2012;87:114-123.

7. Arredondo M, Núñez MT. Iron and copper metabolism. Mol Aspects Med. 2005;26:313-327.

8. Simka M, Rybak Z. Hypothetical molecular mechanisms by which local iron overload facilitates the development of venous leg ulcers and multiple sclerosis lesions. Med Hypotheses. 2008;71:293-297.

9. Skrzycki M, Czeczot $H$. The role of superoxide dismutase in the arising of tumors. Postępy Nauk Med. 2005;4:7-15.

10. Xu B, Wu SW, Lu CW, et al. Oxidative stress involvement in manganese-induced alpha-synuclein oligomerization in organotypic brain slice cultures. Toxicology. 2013;305:71-78.

11. Prasad AS, Beck FW, Bao B, et al. Zinc supplementation decreases incidence of infections in the elderly: Effect of zinc on generation of cytokines and oxidative stress. Am J Clin Nutr. 2007;85:837-844.

12. Ojeda R, Aljama PA. Chronic microinflammation and endothelial damage in uremia. Nefrologia. 2008;28:583-586.

13. Chiu JJ, Chien S. Effects of disturbed flow on vascular endothelium: Pathophysiological basis and clinical perspectives. Physiol Rev. 2011; 91:327-387.

14. Karatepe $O$, Unal O, Ugurlucan M, et al. The impact of valvular oxidative stress on the development of venous stasis ulcer valvular oxidative stress and venous ulcers. Angiology. 2010;61:283-288.

15. Krzyściak W, Kózka M, Kowalska J, Kwiatek WM. Role of Zn, Cu-trace elements and superoxide dismutase (SOD) in oxidative stress progression in chronic venous insufficiency (CVI). Przegląd Lek. 2010;67: 446-449.

16. Plum LM, Rink $L$, Haase $H$. The essential toxin: Impact of zinc on human health. Int J Environ Res Public Health. 2010;7:1342-1365.

17. Chasapis CT, Loutsidou AC, Spiliopoulou CA, Stefanidou ME. Zinc and human health: An update. Arch Toxicol. 2012;86:521-534.

18. Leone N, Courbon D, Ducimetiere P, Zureik M. Zinc, copper, and magnesium and risks for all-cause, cancer, and cardiovascular mortality. Epidemiology. 2006;17:308-314.

19. Tisato F, Marzano C, Porchia M, Pellei M, Santini C. Copper in diseases and treatments, and copper-based anticancer strategies. Med Res Rev. 2010;30:708-749.

20. Saari JT, Schuschke DA. Cardiovascular effects of dietary copper deficiency. Biofactors. 1999;10:359-375.

21. Gupta A, Lutsenko S. Human copper transporters: Mechanism, role in human diseases and therapeutic potential. Future Med Chem. 2009; 1:1125-1142.

22. Cromwell GL. Copper as a nutrient for animals. In: Richardson HW, ed. Handbook of Copper Compounds and Applications. Boca Raton, FL: CRC Press; 1997.

23. Tuschl K, Mills PB, Clayton PT. Manganese and the brain. Int Rev Neurobiol. 2013;110:277-312.

24. Hirata Y. Manganese-induced apoptosis in PC12 cells. Neurotoxicol Teratol. 2002;24:639-653.
25. Erikson KM, Aschner M. Manganese neurotoxicity and glutamateGABA interaction. Neurochem Int. 2003,43:475-480.

26. Tohno S, Tohno $Y$, Minami T, et al. A high accumulation of minerals in human internal jugular vein. Biol Trace Elem Res. 1998;62:17-23.

27. Tohno S, Tohno Y, Masuda M, et al. A possible balance of magnesium accumulations among bone, cartilage, artery, and vein in single human individuals. Biol Trace Elem Res. 1999;70:233-241.

28. Pilotelle-Bunner A, Cornelius F, Sebban P, Kuchel PW, Clarke RJ. Mechanism of $\mathrm{Mg}^{2+}$ binding in the $\mathrm{Na}^{+}, \mathrm{K}^{+}$-ATPase. Biophys J. 2009;96:3753-3761.

29. Rude RK, Singer FR, Gruber HE. Skeletal and hormonal effects of magnesium deficiency. J Am Coll Nutr. 2009;28:131-141.

30. Nielsen FH, Milne DB, Klevay LM, Gallagher S, Johnson L. Dietary magnesium deficiency induces heart rhythm changes, impairs glucose tolerance, and decreases serum cholesterol in post menopausal women. J Am Coll Nutr. 2007;26:121-132.

31. Kolte D, Vijayaraghavan K, Khera S, Sica DA, Frishman WH. Role of magnesium in cardiovascular diseases. Cardiol Rev. 2014;22:182-192.

32. Ross AC, Taylor CL, Yaktine AL, Del Valle HB. Dietary Reference Intakes for Calcium and Vitamin D. Washington, DC: National Academies Press; 2011.

33. Yáñez M, Gil-Longo J, Campos-Toimil M. Calcium binding proteins. Adv Exp Med Biol. 2012;740:461-482.

34. Brini M, Ottolini D, Calì T, Carafoli E. Calcium in health and disease. Met lons Life Sci. 2013;13:81-137.

35. Pruksa S, Siripinyanond A, Powell JJ, Jugdaohsingh R. Silicon balance in human volunteers: A pilot study to establish the variance in silicon excretion versus intake. Nutr Metab (Lond). 2014;11(1):4. doi: 10.1186/1743-7075-11-4

36. Martin KR. Silicon: The health benefits of a metalloid. Met lons Life Sci. 2013;13:451-473.

37. Jugdaohsingh R, Watson AIE, Pedro LD, Powell JJ. The decrease in silicon concentration of the connective tissues with age in rats is a marker of connective tissue turnover. Bone. 2015;75:40-48.

38. Gropper S, Smith J. Nonessential Trace and Ultratrace Elements. Advanced Nutrition and Human Metabolism. $6^{\text {th }}$ ed. Belmont, CA:Wadsworth; 2013.

39. Mertz W, ed. Trace Elements in Human and Animal Nutrition. Volume 2. $5^{\text {th }}$ ed. Orlando, FL: Academic Press; 2012.

40. Nakashima Y, Kuroiwa A, Nakamura M. Silicon contents in normal, fatty streaks and atheroma of human aortic intima: Its relationship with glycosaminoglycans. Br J Exp Pathol. 1985;66:123-127.

41. Garcimartín A, Merino JJ, Santos-López JA, et al. Silicon as neuroprotector or neurotoxic in the human neuroblastoma SH-SY5Y cell line. Chemosphere. 2015;135:217-224.

42. Tohno S, Tohno Y, Moriwake Y, Azuma C, Ohnishi Y, Minami T. Quantitative changes of calcium, phosphorus, and magnesium in common iliac arteries with aging. Biol Trace Elem Res. 2001;84:57-66.

43. Myers HL. Topical chelation therapy for varicose pigmentation. Angiology. 1966;17:66-68.

44. Moosavi K, Vatankhah S, Salimi J, Moradi M. A proton induced X-ray emission (PIXE) analysis of concentration of trace elements in varicose veins. Int J Radiat Res. 2010;8:117-121.

45. Aubail A, Méndez-Fernandez $P$, Bustamante $P$, et al. Use of skin and blubber tissues of small cetaceans to assess the trace element content of internal organs. Mar Pollut Bull. 2013;76:158-169.

46. Heidari B, Riyahi Bakhtiari A, Shirneshan G. Concentrations of Cd, $\mathrm{Cu}, \mathrm{Pb}$ and $\mathrm{Zn}$ in soft tissue of oyster (Saccostrea cucullata) collected from the Lengeh Port coast, Persian Gulf, Iran: A comparison with the permissible limits for public health. Food Chem. 2013;141:3014-3019.

47. Döker S, Hazar M, Uslu M, Okan I, Kafkas E, Boşgelmez Ii. Influence of training frequency on serum concentrations of some essential trace elements and electrolytes in male swimmers. Biol Trace Elem Res. 2014;158:15-21.

48. Krebs N, Langkammer C, Goessler W, et al. Assessment of trace elements in human brain using inductively coupled plasma mass spectrometry. J Trace Elem Med Biol. 2014;28:1-7. 